\title{
The Decline of North American Industry
}

\author{
Jorge Niosi and Philippe Faucher
}

During the post-war period North America has not been de-industrialising, if we define this term as an absolute loss of industrial jobs and/or an absolute fall in industrial output. However, it has suffered a decline relative to the world economy as a whole, not only in manufacturing, but also in commerce and finance. This decline is partly due to the rising competitiveness of Japan, Western Europe and several newly industrialising countries (NICs), which have captured large shares of foreign and domestic markets previously served by American products. In the US the decline is also due to the military effort; this is evident both in the use of public R \& D funds, and in the share of defence expenditures in total public expenditures. Continental Europe and Japan are much more concerned with civilian $R \& D$, while the US and UK use most public funds for military research, which has fewer spin-offs for civilian industry.

The following excerpts from two separate papers by Jorge Niosi and Philippe Faucher document for the US and Canada respectively the principal manifestations of economic decline, and briefly discuss the response of the state to the latter.

\section{THE DECLINE OF NORTH AMERICAN INDUSTRY: I USA Jorge Niosi}

\section{US Economic Decline}

On the basis of the data shown in Tables 1 and 2 below we can refute the thesis of an absolute industrial decline in the US economy. Industrial employment (and especially manufacturing employment) shows positive changes during the post-war period (Table 1). Using the absolute employment loss definition, the UK has actually 'de-industrialised' during the last 25 years, losing 25 per cent of its labour force from 1961 to 1981. West Germany, France and the Netherlands have lost some industrial jobs while Canada, the US, Japan and Italy actually increased industrial employ- ment. Nor is there any absolute industrial decline in US production, according to Table 2. Only the UK has experienced a steady industrial depression, with 1982 production levels close to 1972 figures. The US does, however, show slower industrial growth than other advanced competitors apart from the United Kingdom.

Relative industrial decline is, however, evident from Table 3, while relative economic decline can be seen in Table 4. In 1980 the American GDP was one third of that of the OECD, compared with more than 50 per cent in 1960. Slow GDP growth rates in the US account for this relative economic decline.

Contemporary with this relative economic and industrial decline, we also find a commercial decline (see Tables 5, 6 and 7). It should be noted that rival trade powers do not follow the same path: the EEC and Canada increased their share of world exports until the beginning of the 1960s. Only Japan steadily increased its share of world trade throughout the period. However, Table 6 shows that the US is the only country in which the growth rates of exports were regularly below the world average from 1950 to 1981 . The US share of the capitalist world's manufacturing exports has fallen from 22.3 per cent in 1950 to 14.9 per cent in 1981.

Financial decline is also evident from Table 8. During the first 20 years of the post-war period, American banks received large amounts of foreign deposits and made corresponding loans. However, their share of world financing rapidly diminished during the $1960 \mathrm{~s}$. In 1966 British banks regained first place in terms of foreign assets and, in 1970, in terms of foreign liabilities. The US banks have not declined alone: the banks of all developed countries reduced their share of foreign assets and liabilities of deposit banks in the capitalist world, while several banks in the Arab countries and in the NICs increased their share correspondingly.

IDS Bulletin. 1985, vol 16 no 2, Institute of Development Studies, Sussex 
Principal industrial countries: changes in labour force, 1961-81

\begin{tabular}{|c|c|c|c|c|c|}
\hline & \multicolumn{3}{|c|}{$\begin{array}{l}\text { total labour force } \\
\quad(\text { thousands })^{1}\end{array}$} & \multicolumn{2}{|c|}{$\begin{array}{c}\text { average annual } \\
\text { change }(\%)\end{array}$} \\
\hline & 1961 & 1971 & 1981 & $1961 / 71$ & $1971 / 81$ \\
\hline \multicolumn{6}{|l|}{ USA } \\
\hline all industries & 21,564 & 26,092 & 30,190 & 1.9 & 1.5 \\
\hline manufacturing & - & 19,066 & 21,817 & - & 1.1 \\
\hline \multicolumn{6}{|l|}{ CANADA } \\
\hline all industries & 1,979 & 2,470 & 3,094 & 2.2 & 2.3 \\
\hline manufacturing & 1,452 & 1,766 & 2,120 & 2.1 & 1.8 \\
\hline \multicolumn{6}{|l|}{ UK } \\
\hline all industries & 11,190 & 11,104 & 8,503 & -0.7 & -2.7 \\
\hline manufacturing & 9,215 & 8,754 & - & -0.8 & - \\
\hline \multicolumn{6}{|l|}{ FRG } \\
\hline all industries & 12,932 & 12,741 & 11,123 & -0.1 & -1.4 \\
\hline manufacturing & - & 9,835 & 8,601 & - & 1.3 \\
\hline \multicolumn{6}{|l|}{ ITALY } \\
\hline all industries & 7,646 & 7,617 & 7,728 & 0.0 & 0.1 \\
\hline manufacturing & 5,485 & - & 5,388 & - & - \\
\hline \multicolumn{6}{|l|}{ FRANCE } \\
\hline all industries & 7,132 & 8,113 & 7,391 & 1.2 & -0.9 \\
\hline manufacturing & - & 5,726 & 5,269 & - & -0.8 \\
\hline \multicolumn{6}{|l|}{ NETHERLANDS } \\
\hline all industries & 1,666 & 1,670 & 1,486 & 0.0 & -1.2 \\
\hline manufacturing & 1,185 & 1,118 & 1,039 & 0.1 & -0.7 \\
\hline \multicolumn{6}{|l|}{ IAPAN } \\
\hline all industries & 13,460 & 18,450 & 19,700 & 3.2 & 0.7 \\
\hline manufacturing & 10,110 & 13,830 & 13,850 & 3.2 & 0.0 \\
\hline
\end{tabular}

' 'All industries' includes resource extraction, manufacturing, public utilities and building.

Source: OECD, several issues, Labour Force Statistics, Paris

These data refute the thesis that the US has maintained economic supremacy in the Western world. By the beginning of the 1980s the US was only one industrial power among others - the largest market economy, but not a hegemonic power. The data also refute the three-stage pattern of decline suggested by Wallerstein [1982]. In the case of the US, industrial, commercial and financial decline have occurred simultaneously.
The argument which seeks to explain US deindustrialisation as a result of direct investment abroad [Bluestone and Harrison 1982] is similar to that which explains the decline caused by the transfer of manufacturing production abroad [Magdoff 1979]. Both hypotheses receive some confirmation from Table 9, which shows that US corporations are doing an increasing proportion of their industrial production 
Principal industrial countries: industrial production (index numbers, $1967=100$ )

\begin{tabular}{lccccccccc} 
& & & & & & & & & $\begin{array}{c}\text { average } \\
\text { of all } \\
\text { countries }\end{array}$ \\
\hline 1970 & 108 & 120 & 131 & 118 & 137 & 111 & 152 & 115 & 130 \\
1977 & 138 & 152 & 152 & 145 & 176 & 123 & 190 & 152 & 158 \\
1978 & 146 & 154 & 154 & 148 & 178 & 127 & 201 & 158 & 163 \\
1979 & 153 & 161 & 162 & 158 & 183 & 132 & 215 & 167 & 175 \\
1980 & 147 & 160 & 162 & 167 & 183 & 124 & 225 & 165 & 176 \\
1981 & 151 & 157 & 160 & 163 & 179 & 119 & 228 & 167 & 175 \\
1982 & 139 & 156 & 156 & 159 & 175 & 119 & 228 & 149 & 173 \\
\hline
\end{tabular}

Source: US Department of Commerce, International Economic Indicators, Washington DC

Table 3

US share of world manufacturing value added, 1948-79 (\%)

\begin{tabular}{lcc}
\hline year & current prices & constant prices \\
\hline 1948 & 56.7 & \\
1953 & 55.3 & \\
1958 & 34.2 & \\
1963 & 37.6 & 29.7 \\
1970 & & 21.3 \\
1975 & & 21.7 \\
1979 & & \\
\hline
\end{tabular}

Source: Ballance, R. and S. Sinclair 1983, Collapse and Survival: industry strategies in a changing world, George Allen and Unwin, London, pl6

Table 4

National shares of total OECD GDP, $1960-80(\%)$

\begin{tabular}{lccccccc}
\hline year & USA & Japan & FRG & France & UK & Canada & $\begin{array}{c}\text { total GDP OECD } \\
\text { (\$US bn) }\end{array}$ \\
\hline 1960 & 53 & 5 & 8 & 6 & 8 & 4 & 944 \\
1965 & 50 & 7 & 8 & 7 & 7 & 4 & 1,388 \\
1970 & 47 & 10 & 9 & 7 & 6 & 4 & 1,927 \\
1975 & 38 & 12 & 10 & 8 & 6 & 4 & 4,081 \\
1980 & 34 & 14 & 11 & 9 & 7 & 3 & 7,544 \\
\hline
\end{tabular}

Source: OECD, several issues, National Accounts, Paris 
Shares of total world exports by value, 1950-81 (\%)

\begin{tabular}{|c|c|c|c|c|c|c|c|c|}
\hline & \multicolumn{8}{|c|}{ shares of total world exports ${ }^{1}$} \\
\hline & 1950 & 1955 & 1960 & 1965 & 1970 & 1975 & 1980 & 1981 \\
\hline USA & 16.7 & 16.4 & 15.9 & 14.5 & 13.7 & 12.3 & 11.0 & 11.8 \\
\hline EEC & 26.8 & 30.4 & 32.6 & 34.4 & 35.6 & 34.0 & 32.9 & 30.5 \\
\hline Japan & 1.4 & 2.1 & 3.2 & 4.5 & 6.1 & 6.4 & 6.5 & 7.7 \\
\hline Canada & 4.8 & 4.7 & 4.3 & 4.3 & 5.1 & 3.7 & 3.2 & 3.5 \\
\hline \multirow{2}{*}{$\begin{array}{l}\text { Socialist } \\
\text { bloc }\end{array}$} & & & & & & & & \\
\hline & 8.1 & - & 11.7 & - & 10.6 & - & - & 9.2 \\
\hline
\end{tabular}

${ }^{1}$ calculated on fob exports, current dollars

Source: UNCTAD, several issues, Handbook of International Trade and Development Statistics, Geneva

Table 6

Growth in exports, 1950-81 (\%)

average annual growth in exports ${ }^{1}$

\begin{tabular}{lrrrr} 
& $1950-60$ & $1960-70$ & $1970-80$ & $1950-81$ \\
\hline world & 6.4 & 9.3 & 20.4 & 11.7 \\
USA & 5.1 & 7.8 & 18.2 & 9.7 \\
EEC & 8.5 & 10.1 & 19.4 & 12.4 \\
Canada & 5.3 & 11.8 & 14.9 & 10.6 \\
Japan & 15.9 & 17.5 & 20.8 & 18.1 \\
\hline
\end{tabular}

${ }^{1}$ calculated on fob exports, current dollars

Source: UNCTAD, several issues, Handbook of International Trade and Development Statistics, Geneva

Table 7

Shares of exports of manufactured products from capitalist countries, 1960-81 (\%)

\begin{tabular}{lrrrrrr}
\hline & 1960 & 1965 & 1970 & 1975 & 1980 & 1981 \\
\hline USA & 22.3 & 19.1 & 16.1 & 15.1 & 13.8 & 14.9 \\
EEC & 55.7 & 55.9 & 49.4 & 49.6 & 48.0 & 43.2 \\
Japan & 6.2 & 8.6 & 9.9 & 11.3 & 11.9 & 14.1 \\
Canada & 4.3 & 4.2 & 5.3 & 3.5 & 3.3 & 3.6 \\
\hline
\end{tabular}

Source: UN, several issues, Monthly Bulletin of Statistics, New York 
Foreign assets of deposit banks, 1963-82 (\%)

\begin{tabular}{|c|c|c|c|c|c|}
\hline & 1963 & 1967 & 1972 & 1977 & 1982 \\
\hline USA & 26.5 & 36.2 & 7.1 & 10.2 & 18.3 \\
\hline Canada & 10.1 & 3.7 & 3.2 & 2.1 & 1.7 \\
\hline Japan & 8.2 & 6.4 & 3.5 & 2.5 & 4.0 \\
\hline France & $*$ & $*$ & 7.8 & 8.4 & 6.4 \\
\hline FRG & 9.7 & 4.0 & 6.0 & 6.7 & 3.6 \\
\hline Belgium & 3.0 & 3.7 & 3.2 & 3.3 & 2.9 \\
\hline Luxembourg & 1.1 & 0.7 & 8.4 & 5.9 & 4.6 \\
\hline Switzerland & $*$ & $*$ & 13.2 & 8.2 & 7.2 \\
\hline UK & 19.3 & 22.2 & 23.4 & 19.4 & 20.4 \\
\hline sub-total & 77.9 & 76.9 & 75.8 & 66.7 & 69.1 \\
\hline industrialised countries & 89.9 & 95.8 & 86.5 & 76.1 & 76.9 \\
\hline all countries $(\%)$ & 100.0 & 100.0 & 100.0 & 100.0 & 100.0 \\
\hline (\$US bn) & 26.7 & 64.5 & 255.0 & 867.4 & 2267.9 \\
\hline
\end{tabular}

Source: IMF, 1983, International Financial Statistics, New York, IMF

Table 9

Manufacturing exports and foreign sales of US firms, 1960-77

\begin{tabular}{lccc}
\hline year & \multicolumn{1}{c}{$\begin{array}{c}2 \\
\text { manufacturing exports }\end{array}$} & $\begin{array}{c}\text { sales by foreign affiliates } \\
\text { of US }\end{array}$ \\
& \multicolumn{4}{c}{ \$US bn, current dollars } \\
\hline 1960 & 12.3 & 23.6 & 1.9 \\
1965 & 17.2 & 42.4 & 2.5 \\
1970 & 29.1 & 78.3 & 2.7 \\
1977 & 77.7 & 246.3 & 3.2 \\
\hline
\end{tabular}

Sources: UNCTAD, several issues, Handbook of International Trade and Development Statistics, Geneva

US Department of Commerce, several issues, Survey of Current Business, Washington DC

abroad in order to capture foreign markets. These figures, however, have to be considered in the light of the following remarks. US corporations have not been alone in multinational expansion; other countries' large firms have not only adopted the same strategy, but the rate of increase of their overseas investment has been faster. Not only is the American economy itself being invaded by European, Japanese and Canadian multinational corporations which are carving out increasingly important niches for themselves in the economy, but many studies show the displacement of American goods by other countries' exports in many foreign markets [Roemer 1975; Baranson 1981]. In short, the multinational expansion of US manufacturing firms seems to be only a phase in the US decline. Multinational isation is not a factor of decline, but a means of slowing it down, enabling US firms to shelter from European and Japanese competition behind the protectionist barriers of client countries. Nevertheless, US overseas investment is growing more and more slowly. In 1982, for the first time since the Second World War, it fell in absolute terms by nearly $\$$ US6 bn. Multinationals have not been insulated from the crisis, as Andreff [1982] argues, nor, contrary to Balassa's predictions [1982], has the revaluation of the dollar increased US overseas investments. 
Principal industrial countries, military expenditures 1961-80 (\%)

military expenditures as a \% of total public expenditure

$1961-70$

$1971-80$

\begin{tabular}{lrr}
\hline USA & 44 & 25 \\
UK & 17 & 14 \\
France & 19 & 8 \\
FRG & 16 & 11 \\
Japan & 6 & 5
\end{tabular}

Source: UN, several issues, Statistical Yearbook, New York

Table 11

Principal OECD countries, public financing of R \& D by sector, 1981 (\%)

\begin{tabular}{|c|c|c|c|c|c|c|c|}
\hline & \multicolumn{7}{|c|}{ share of total public $R \& D$ financing } \\
\hline & $U S$ & $F R G$ & France & $U K$ & $J_{a p a n^{1}}$ & Italy & Canada \\
\hline defence and space & 65.7 & 12.9 & 41.4 & 54.9 & 16.8 & 12.3 & 6.6 \\
\hline energy, infrastructure & 14.4 & 22.0 & 13.9 & 8.0 & 32.4 & 27.8 & 25.0 \\
\hline agriculture, industry & 2.5 & 12.8 & 12.7 & 11.6 & 35.6 & 21.6 & 33.2 \\
\hline health, welfare & 13.6 & 10.0 & 6.7 & 3.3 & 11.2 & 5.9 & 14.0 \\
\hline $\begin{array}{l}\text { promotion of } \\
\text { knowledge }\end{array}$ & 3.8 & 42.3 & 24.6 & 22.4 & 4.1 & 32.4 & 21.3 \\
\hline total & 100.0 & 100.0 & 100.0 & 100.0 & 100.0 & 100.0 & 100.0 \\
\hline total (\$US bn) & 35.5 & 7.3 & 7.0 & 6.3 & 5.5 & 2.9 & 1.4 \\
\hline
\end{tabular}

${ }^{1}$ data for 1980

Source: OECD, 1983, Informations no 7, Paris

Other explanations of US economic decline seem to fit the facts better. The thesis of the military burden is strongly confirmed both by cross-national data on military expenses as a proportion of total expenses (Table 10), and on public financing of R \& D (Table 11).

In 1981 only 2.5 per cent of publicly financed R \& D in the US went into agriculture and industry, while the equivalent figures for Japan and Canada were roughly 33 per cent. At the same time 65 per cent of public funds in R \& D went to military activities in the US, 55 per cent of British funds but only 17 per cent in Japan, 13 per cent in West Germany and 12 per cent in Italy (see Table 11). Besides, military expenditures represented a larger proportion of total government expenditures in the US than in any other industrial country (Table 10). Between 1961 and 197044 per cent of all US federal expenses went to defence; that figure fell to 25 per cent between 1971 and 1980 but it remained substantially higher than in other countries. Once again, Japan is the advanced industrial country least burdened by military expenditures, while the US is the most burdened.

As to labour costs, US production workers in manufacturing received compensation substantially higher than their European or Japanese counterparts from 1945 to 1970 . For the last 10 years (1973 to 1983) this is no longer so; compensation grew much more rapidly in Western Europe and Japan than in the US, and wages are now equivalent to those in America in most developed countries. Of course, comparative 
advantages in labour intensive goods still hold for all NICs, against US goods.

\section{The US Response to Economic Decline}

From 1945 to 1965 a small portion of the American economy was exposed to world competition. Since then this portion has increased dramatically, due to the lowered tariff barriers following the GATT rounds, to improved international transportation and to the growth of production and productivity in other industrial and newly industrialised countries. From 1969 to 1980 the ratio of imports to final sales of goods in the US rose from eight per cent to 21 per cent. The US economy is now much more vulnerable to foreign competitors than it was 20 years ago. Several authors estimate that nearly 70 per cent of US manufacturing production is now exposed to international markets [Magaziner and Reich 1983].

This growing exposure of the US market, combined with the improved industrial performance of its competitors has produced increasing deficits in the US trade balance for tangible goods. Since 1975 this trade account has been negative. Estimates for 1983 show a negative balance of $\$ 65.5 \mathrm{bn}$, and forecasts for 1984 put the deficit at $\$ 100$ bn.

Several items of this trade balance are worth a more careful analysis. Official statistics of US foreign commerce divide it into five major sectors. The automobile trade, one of the most important, was largely positive from 1945 to 1970 , then became increasingly negative, in spite of the 'voluntary' restrictions on Japanese car exports to the US. In this key industry, responsible for 15 per cent of American jobs, the US share of world production fell from 79 per cent to 19 per cent between 1946 and 1982; meanwhile, the Japanese share increased from zero to 27 per cent; West Germany and France also took growing shares of the market. Imported cars now serve 30 per cent of the US market, while US production fell from a peak of $11.1 \mathrm{mn}$ cars and trucks in 1965 to $6.9 \mathrm{mn}$ in 1982. The slight increase in 1983 production is largely explained by the impact of protectionist measures imposed by the American Government against Japanese imports since 1981.

The US trade deficit is also growing in two other major categories, namely intermediary and consumer industrial goods, while surpluses are increasing in agricultural products and capital goods. In the latter division, however, the crucial machine-tools trade has shown an increasing deficit since 1976, due to European and Japanese competitors capturing foreign and domestic markets as well.

To reduce the devastating effects of the decline in US competitiveness, the federal government has adopted several measures. These do not constitute a comprehensive 'industrial policy', but they are a systematic and coherent set of responses. They can be summarised in three points: non-tariff protectionism, bail-outs and labour cost reductions.

As to protectionism, tariffs have fallen steadily during the post-war period, mainly through the GATT rounds. However the US Government has developed another kind of protectionism, as effective as the first one, namely non-tariff barriers. One of the main forms of this new protectionism is 'voluntary' restrictions on foreign exports, by which foreign countries have accepted to limit or reduce their exports to the US under the threat of an increased US tariff or other unilateral measure. For example, in 1962 the US signed a multilateral agreement limiting the imports of cotton textiles; in 1974 the Multi-Fiber Agreement Regarding International Trade in Textiles included 18 bilateral agreements regulating US imports of a variety of textiles and apparel. Japan was the first country to be restricted by these agreements, but soon South Korea, Hong Kong, Taiwan and Brazil were also affected. In 1977 a similar agreement was imposed upon Japan, restricting Japanese exports of colour TV sets to the US; this agreement was extended to South Korea in 1978. Meanwhile, since 1969, several agreements for 'voluntary' restrictions on steel exports have been signed with a number of industrial countries, and in 1981 Japan had to accept export quotas on its car exports to the US. Therefore, these non-tariff agreements now cover several major industries including textiles, apparel, shoes, steel, automobiles, and colour TV receivers. The number of protected industries grows continuously, with machinetools likely to be the next one. Together with Italy the US is the most protectionist of the seven largest industrial countries: in both cases 34 per cent of imports are restricted by non-tariff barriers. As for bail-outs, that of Chrysler in 1981 through the federal government underwriting $\$ 1.2$ bn in bank loans is well known, but the tax reductions accorded to the steel industry in 1982 are at least as important. Finally, since the beginning of the 1970s the US government and large corporations have been looking for wage freezes, the abandonment of wage indexation clauses, productivity gains and cuts in non-wage costs. As a result of this combined attack, labour costs in the US have grown at a slower pace than in other industrial countries. Labour costs are no longer an important factor in the American economic decline.

But these different measures have not arrested the industrial decline in the US. They have probably slackened its pace, but they have also contributed to reducing productivity gains and accelerating the loss of foreign markets for US industrial goods. 
In the near future two main alternatives seem possible. The first is the continuation of present trends and policies: economic decline and increasing non-tariff protection, with bail-out operations intended to save a large firm or a specific industry from bankruptcy. This is what I call the 'British' option, adopted at the beginning of this century in the UK and its Empire. This path can slow down economic decline without completely stopping it or reversing the long-term trend. In this case the US would become a large exporter of agricultural products and might retain a technological lead in some capital goods industries.

The second option is that of an active industrial policy to support sunrise industries, favour the retraining of workers in declining industries, push innovation and develop scientific and technical education. In other words the adoption of the 'Japanese' option, based upon the founding of a dynamic capitalism, passing from one industry to another under the guidance of an interventionist state. If the first option is that of the Republicans, the second is the Democratic one. In fact, the Democratic Party has made many industrial policy propositions, and it is not easy to say which one has most chance of being adopted. All of them, however, include a certain amount of protectionism and a more selective interventionist state than the Republican option.

\section{Reference}

Andreff, W., 1982, Les Multinationales Hors la Crise, Le Sycomore, Paris

Balassa, B., 1982, 'Les Etats Unis dans l'économie mondiale', Economie Prospective Internationale, no 9, Paris

Baranson, J., 1981, The Japanese Challenge to US Industry, Lexington Books, Lexington, Mass.

Bluestone, B. and B. Harrison, 1982, The Deindustrialization of America, Basic Books, New York

Magaziner, I. and R. Reich, 1983, Minding America's Business: The Decline and Rise of the American Economy, Random House, New York

Magdoff, H., 1979, 'The dollar, petro-dollars and US imperialism', Monthly Review

Roemer, J., 1975, US Japanese Competition in the International Market, University of California Press, Berkeley

Wallerstein, I., 1982, 'North Atlanticism in decline', $S A I S$ Review, no 4 


\title{
The Decline of North American Industry: II Canada
}

\author{
Philippe Faucher
}

\section{Canadian Industrial Decline}

Unlike Great Britain, which is experiencing a real process of de-industrialisation, the contribution of the manufacturing sector to GDP has declined only slightly in Canada, as it has in most OECD countries. However, since the Canadian economy has been growing for the past 10 years at a rate inferior to that of most European nations, Canada's industrial production index of 167 in $1981(1967=100)$ was significantly below the mean index of major industrial countries (175 in 1981). The data also show that Canada was hard hit by the most recent recession, during which industrial production declined by almost 11 per cent in 1982.

Industrial decline is not a recent phenomenon in Canada. Manufacturing ceased to be the major activity leading Canada's economic growth in 1974. This fact appears very clearly when the growth rate of GDP is compared to that of industrial production. This trend, which appears when looking at international comparisons, is confirmed in a much more worrisome manner when we look at the national data on productivity, employment and trade.

Declines in productivity, which were unknown in the 1960 s, occurred four times in the 1970s. The average growth in output per person employed in Canada between 1973 and 1980 was marginally negative ( -0.2 per cent), as compared with positive rates in West Germany ( +2.9 per cent), Italy ( +2.1 per cent) and Japan (+4.1 per cent). A more accurate measure of productivity is the average growth in output per person-hour worked. For the latter, the average annual rate in Canadian manufacturing between 1975 82 was only one per cent.

Employment is certainly a major variable in evaluating the scale of industrial decline. Although total employment in Canada has increased significantly since 1970 (+34 per cent until 1982) absolute employment in the manufacturing sector has remained stable and is now responsible for a lesser share ( -4 per cent) of total employment. The sector most affected by the decline in employment is the durable goods industry. The employment index for the latter, that had reached 149 in $1974(1961=100)$, was down to 122 in 1982 , the fall taking place essentially during the 1981 recession.

The steady increase in unemployment should also be mentioned. The data show that not only has unemployment risen absolutely, but that it has been increasing faster than the economically active population. The unemployment rate which in the $60 \mathrm{~s}$ was around five per cent, reached six per cent in the 1970 s, passed the eight per cent mark in the late 1970s, and has been well above 10 per cent since 1982. This increase indicates that an increasing proportion of those willing to work cannot find employment. Even allowing for the growing number of those looking for work, we are faced with an absolute decline in the availability of jobs in the manufacturing sector.

Though Canadian trade should receive much attention, we have space to look at only two dimensions of this complex issue. On a global scale, Canada was responsible in 1970 for six per cent of world trade; 10 years later we were down to 3.7 per cent. Even taking into account exchange rate differences and fluctuations in prices, this is a very sharp drop. Canada now depends on trade for more than 29 per cent of its GDP, which is much higher than most developed countries with the exception of the Netherlands, Belgium and Luxembourg. Given the instability of foreign markets and the considerable fluctuation of currency rates, and because two thirds of Canadian trade is with the United States ( 25 per cent of which is intra-firm trade), Canada is today much more dependent than in the past on cyclical changes in the American economy and on fiscal and monetary policy decided upon in Washington.

The composition of Canadian exports should certainly be of major concern. Of the goods exported,

IDS Bulletin, 1985, vol 16 no 2, Institute of Development Studies, Sussex 
only 32 per cent are finished goods, of which automobiles represent in most years 20 per cent. There is a positive trade balance for manufactured wood products, pulp and paper, metals and petroleum, all of which are in the early stages of transformation, with little value added. The final product trade balance alone is responsible for a huge deficit. The Economic Council of Canada claims that this is not a cause for concern since our export/import ratio for final products has increased significantly over the years: from 30 per cent in the mid-1960s to between 50 and 60 per cent from 1968 until now. However, it must be noted that this ratio reached an all-time high of 64.4 per cent in 1970 and has been declining since then, while the overall trade deficit has reached enormous proportions. In 1964, when the ratio was still 30 per cent, the trade deficit amounted to $\$ 2.6 \mathrm{bn}$; in 1981 a 55 per cent ratio corresponded to a $\$ 21$ bn deficit. There is little cause for complacency in this rising ratio.

A complete picture of industrial decline would require an examination of $R \& D$ expenditures, regional development and the evolution of specific sectors, the so-called sunset and sunrise industries. However, it is sufficient to note that each would confirm our analysis of weaknesses and inadequacies in the Canadian industrial sector.

\section{Canadian Industrial Adjustment Policies}

Since World War II, and more systematically for the past 25 years, the Canadian Government (and the Provincial governments as well) have been involved in actively supporting production in manufacturing through different instruments such as tariffs, subsidies, loans and fiscal incentives. We shall briefly look at their evolution, and at the orientation taken by these policy instruments.

It is a well known fact that tariffs have declined significantly over the past 25 years, while the volume of duty-free imports has climbed, now reaching 70 per cent of the total value of imports (45.8 per cent in 1979 for manufactured goods). It is frequently mentioned that quotas and voluntary export restrictions are actually offsetting the decline in tariffs. This is certainly not true for Canada. Among the thousands of products that are currently shipped into Canada, import agreements and quotas are applied only to textiles ( 21 products) and clothing (17 products) and more recently to passenger cars from Japan. Studies have shown that the only impact of these measures, which are costly to the consumer and have a damaging effect on the structure of the industries concerned, has been to slow down temporarily the penetration of Canada's domestic market by foreign products. Therefore, it appears that for restructuring purposes, trade policy is a weak instrument, particularly since national control is limited by the international procedures under which tariffs are negotiated.

In financial terms, fiscal incentives are the most important instrument of government intervention towards manufacturing industries. From 1973 to 1979 we note a regular increase in fiscal incentives in relation to value added. These incentives are designed mainly to stimulate investment and encourage expenditures in R \& D.

By looking at the real imposition rates of different categories of firms we can measure the sectoral impact of fiscal incentives. It appears that these favour those industries which are capital-intensive (primary metals, non-ferrous metals, petroleum and coal) against labour-intensive industries (shoes, textiles). This means that big firms, which are more common in the capital intensive industries and which are able to tailor their investments in order to maximise their use of all available incentives, receive the most benefits. At the other end of the scale, small firms can take advantage of special tax credits and lower interest rate programmes specially created for them.

This situation is not unique to Canada and has been documented for other countries such as the United States and Britain. Fiscal incentives are essentially targeted towards expanding sectors, since to claim a tax credit or a deduction a business has to declare a profit and engage in capital investment. This is particularly unsuitable for declining industries. Therefore it appears once again that the way the policy has been designed limits the structural impact of fiscal incentives.

Direct financial assistance includes subsidies, loans and loan guarantees. Until 1967 almost 70 per cent of direct subsidies were applied to shipbuilding and defence related industries (mostly aeronautics). Between 1965 and 1970 , numerous programmes were created and regional development became a major concern of the federal government. Overall financial assistance to industry reached a peak of $\$ 270 \mathrm{mn}$ in 1971 and (in 1971 constant dollars) has decreased in the following decade, catching up to its previous level only in the past two years. As industrial decline became more apparent, government intervention through assistance actually diminished. There are two causes for the latter. First, major programmes were cut because of government budgetary constraints. Second, since most programmes are linked to investment, the diminution of transfers reflects the overall slowdown of private investment in manufacturing. Direct financial aid is the policy instrument that can be most effectively manipulated in a discriminatory fashion, but it has seldom been used in 
this way. For example, financial support is only exceptionally available to businesses that are experiencing real financial and structural difficulties.

Our survey of past practices makes us believe that the design of the policy instruments makes them by and large inadequate to address efficiently the problem of Canadian industrial decline. In summary our arguments are as follows:

- most programmes were created in a period of rapid economic growth to stimulate production. The government's intervention has declined while the rate of growth of production has collapsed. Only recently has there been a change in policy orientation (as indicated by the creation of the Canadian Industrial Renewal Board);

- programmes are not designed to cope with the structural problems of declining industries;
- government intervention has always stopped short of interfering with the market (which is by definition what a structural policy should do). Programmes are exclusively created to remedy socalled market imperfections (credit gaps, externalities);

- until very recently policy instruments were not applied in an integrated fashion, and no conditions were imposed on the firms to qualify for public funding;

- finally, as a general rule, there is only limited help available to stimulate employment or to reduce the cost to labour of industrial decline. Employment is still considered a function of investment. It is believed that to encourage investment is to indirectly promote employment. But today, for a firm to invest in order to modernise its productive process may also mean that it will diminish its work force. The social security net is supposed to take care of the needs of the unemployed. 